\title{
Bone Marrow-Derived Regenerated Smooth Muscle Cells Have Ion Channels and Properties Characteristic of Vascular Smooth Muscle Cells
}

\section{Ryota Hashimoto${ }^{1}$, Kyoko Nakamura ${ }^{1}$, Seigo Itoh ${ }^{2}$, Hiroyuki Daida ${ }^{2}$, Yuji Nakazato ${ }^{4}$, Takao Okada ${ }^{1}$ and Youichi Katoh ${ }^{2,3 *}$}

${ }^{1}$ Department of Physiology, Juntendo University Faculty of Medicine, Tokyo, Japan

${ }^{2}$ Department of Cardiology, Juntendo University Graduate School of Medicine, Tokyo, Japan

${ }^{3}$ Juntendo University Faculty of International Liberal Arts, Tokyo, Japan

${ }^{4}$ Center for Environmental Research, Department of Cardiology, Juntendo University School of Medicine, Urayasu Hospital, Chiba, Japan

\begin{abstract}
Rationale: Numerous reports, including our own, have recently suggested the presence of putative smooth muscle progenitor cells in the bone marrow (BM) and those smooth muscle-like cells may be differentiated from BM stromal cells (BMSCs). However, few studies have addressed whether the differentiated cells also possess the functional properties of smooth muscle cells (SMCs). Contractility is the primary function of native vascular SMCs.
\end{abstract}

Objective: The aim of this electrophysiological study was to characterize BM-derived SMCs using the patchclamp technique and $\mathrm{Ca}^{2+}$ imaging with fura-2.

Methods and results: To investigate whether BM-derived SMCs exhibit functional vascular SMC properties, we measured $\mathrm{Ca}^{2+}$ and $\mathrm{K}^{+}$currents in BM-derived SMCs using the whole-cell patch-clamp method. The cells showed L-type and T-type $\mathrm{Ca}^{2+}$ channel currents, $\mathrm{Ca}^{2+}$-activated $\mathrm{K}^{+}$channel $\left(\mathrm{K}_{\mathrm{Ca}}\right)$ currents, and delayed rectifier $\mathrm{K}^{+}$channel $\left(\mathrm{K}_{\mathrm{v}}\right)$ currents. We also measured agonist-evoked $\left[\mathrm{Ca}^{2+}\right]_{i}$ transients in BM-derived SMCs using fura-2 imaging. Such $\left[\mathrm{Ca}^{2+}\right]$ transients were observed in response to the vascular SMC-specific agonists, bradykinin $\left(10^{-6} \mathrm{M}\right)$ and angiotensin II $\left(10^{-7} \mathrm{M}\right)$.

Conclusions: BM-derived SMCs displayed contractile activity and expressed several ion channels critical for contractile behavior in a manner compatible with native vascular SMCs. BMSC-derived cells thus have the potential to differentiate into functional vascular SMCs, suggesting bone marrow stromal tissue as a useful source of cells for the treatment of injured arteries and to construct tissue-engineered grafts for adult arterial revascularization.

Keywords: Smooth muscle cells; Bone marrow-derived; Vascular grafts; Arterial pressure; Contractility; Ion channels; Tissue engineering

\section{Introduction}

The construction of stable blood vessels is a fundamental challenge for tissue engineering in regenerative medicine. One of the most important issues in vascular tissue engineering remains the availability of reliable and expandable cell sources for constructing tissueengineered vascular grafts for use in adult arterial revascularization [1], and particularly smooth muscle cell (SMC) sources [2]. We and others previously demonstrated that smooth muscle-like cells can be derived from bone marrow (BM) cells (BMC) both in vitro [3] and in vivo [4]. However, the functional property of these cells such as force generation or contractile activities were not investigated and therefore, it remains unclear whether these cells are functionally equivalent to mature SMCs.

The present study investigated the physiological characteristics of BM-derived SMCs, including contractile activity and $\mathrm{Ca}^{2+} / \mathrm{K}^{+}$currents. Electrophysiological experiments using patch clamping and $\mathrm{Ca}^{2+}$ imaging with fura-2 were conducted to characterize the BM-derived cells, with differentiated SM-like cells exhibiting a contractile function similar to that of native smooth muscle. The BM-derived SMCs also expressed four types of ion-channel currents that are observed in native SMCs. Our study thus describes a source of bone marrow cells for smooth muscle applications, provides a reliable smooth muscle cell source for vascular-tissue engineering, and describes an in vitro system to test the functional capacity of BM-derived SMCs to contract and relax in response to common pharmacological agents.

\section{Materials and Methods}

\section{Cell culture and plasmid construction}

Mononuclear cells obtained by the Ficoll-Paque protocol [5] from murine (C57BL6 mouse) bone marrow $\left(2 \times 10^{5}\right.$ nuclear cells $\left./ \mathrm{ml}\right)$ were plated in 100-mm sterile flasks and cultured in Dexter-type culture medium [6] containing 10\% heat-inactivated horse serum (Sigma). BM-derived adhesion cells appeared within a week (early-phase adhesion cells, E-ad cells) and gradually differentiated into BMSCs over the next 3-7 weeks.A 480-base fragment of the human SM22a promoter [7] was obtained by PCR from human genomic DNA using the following primers: forward 5'-GGATCCCATGTCCCATCAGA-3' and reverse 5'-GGGGCGCTGGCTGGGTGAGG-3'. The fragment was integrated into a promoterless GFP vector (pd2EGFP, Clontech, Mountain View, CA), and then transfected by lipofection $(10 \mu \mathrm{g} / 100$ mm flask; Invitrogen, Carlsbad, CA) into the E-ad cells on the fifth day after seeding of the mononuclear cells. The efficiency of lipofection was $18-32 \%$ in the study. Individual clones were successfully obtained using cloning cylinders (Sigma, St. Louis, MO) and G418 (500 $\mu \mathrm{g} / \mathrm{ml}$, Gibco BRL, Grand Island, NY) selection. GFP-positive clones $(<1 \%$ of total cells) were subsequently cultured for immunochemical staining and

${ }^{*}$ Corresponding author: Youichi Katoh, Department of Cardiology, Juntendo University Graduate School of Medicine, Faculty of International Liberal Arts, 2-1-1 Hongo, Bunkyo-ku, Tokyo112-8421, Japan, Tel: +81-47-353-3111; Fax: +81-47-381-5054; E-mail: katoyo@juntendo-urayasu.jp

Received October 07, 2014; Accepted December 15, 2014; Published December 17,2014

Citation: Hashimoto R, Nakamura K, Itoh S, Daida H, Nakazato Y, et al. (2015) Bone Marrow-Derived Regenerated Smooth Muscle Cells Have lon Channels and Properties Characteristic of Vascular Smooth Muscle Cells. J Stem Cell Res Ther 5: 257. doi:10.4172/2157-7633.1000257

Copyright: (c) 2015 Hashimoto R, et al. This is an open-access article distributed under the terms of the Creative Commons Attribution License, which permits unrestricted use, distribution, and reproduction in any medium, provided the original author and source are credited. 
physiological studies. The smooth muscle cell line of A7r5 cells were used for immunostaining against SMC-specific antibodies.

\section{Immunocytochemistry}

Immunocytochemistry was performed using antibodies recognizing platelet-derived growth factor $\beta$ receptor (PDGF- $\beta$, Santa Cruz Biotechnology, Santa Cruz, CA, diluted 1:250), Flk-1 (Santa Cruz, diluted 1:200), smooth muscle myosin heavy chain (SM) embryo, (SMemb, marker of immature SMC, diluted 1:400), calponin h1 (Santa Cruz, diluted 1:100), alpha-smooth muscle actin ( $\alpha$-SM actin, Biomega, diluted 1:200), and smooth muscle myosin heavy chain-1 (SM-1, marker of mature SMC [8], diluted 1:400). The SMemb and SM-1 antibodies were kindly provided by Dr M. Periasamy.

\section{Northern blot analysis}

RNAs were prepared using an RNeasy total RNA purification kit (Qiagen, Hilden, Germany) and then $20 \mu \mathrm{g}$ of RNA was transferred to nylon membrane (hybond-N+, Amersham Pharmacia, Uppsala, Sweden). The membranes were hybridized with the following probes: a 783-bp murine SM22a cDNA [7], a 841-bp murine calponin cDNA [9], and a 513-bp $\beta$ actin cDNA [10].

\section{Measurement of intracellular free calcium concentration}

Cells plated on glass-bottom dishes were loaded with $3 \mu \mathrm{M}$ fura-2 acetoxymethylester (AM) in the dark for $30 \mathrm{~min}$. The loaded cells were rinsed three times in normal Tyrode's (NT) solution [11] containing (in $\mathrm{mM}$ ) $135 \mathrm{NaCl}, 5.4 \mathrm{KCl}, 1.8 \mathrm{CaCl}_{2}, 1.0 \mathrm{MgCl}_{2}, 5 \mathrm{HEPES}$, and 10 glucose ( $\mathrm{pH}$ was adjusted to 7.4 with $\mathrm{NaOH}$ ), and then incubated in NT solution for an additional $30 \mathrm{~min}$ in the dark at $37^{\circ} \mathrm{C}$ in $5 \% \mathrm{CO}_{2} / 95 \%$ air. Solutions were superfused at a rate of $2 \mathrm{ml} / \mathrm{min}: 10^{-6} \mathrm{M}$ of bradykinin, $10^{-7} \mathrm{M}$ of angiotensin II, or $60 \mathrm{mM}$ of $\mathrm{KCl}$ was applied for 30-60 seconds. Data acquisition and analysis were carried out using AquaCosmos 2.0 (Hamamatsu, Japan).

\section{Electrophysiological measurement}

Cells were plated on coverslips for patch clamping using pipettes that were pulled fresh from plain capillary tubes made of soda-lime glass (Chase Instruments, USA); resistance was 2-4 $\mathrm{M} \Omega$ when pipettes were filled with solution. Membrane currents were recorded using an appropriate patch-clamp amplifier (Axopatch 200A, Axon Instruments, Palo Alto, CA). Data acquisition and analysis were carried out using pClamp software (Axon Instruments). Current signals were filtered at $1 \mathrm{kHz}$ and sampled at a frequency of $5 \mathrm{kHz}$. Cells were voltage clamped [12] at a holding potential of $-80 \mathrm{mV}$, and currents were evoked by +10 $\mathrm{mV}$-increment depolarizing steps of $500 \mathrm{~ms}$ to $+80 \mathrm{mV}$. Ca ${ }^{2+}$ currents were recorded in Cs Tyrode (CsT) solution or high $\mathrm{Ca}^{2+}$ solution. CsT solution contained (in mM) $135 \mathrm{NaCl}, 5.4 \mathrm{CsCl}, 1.8 \mathrm{CaCl}_{2}, 1.0 \mathrm{MgCl}_{2}$, 5 HEPES, and 10 glucose; $\mathrm{pH}$ was adjusted to 7.4 with $\mathrm{NaOH}$. The high $\mathrm{Ca}^{2+}$ solution contained (in $\mathrm{mM}$ ) $135 \mathrm{NaCl}, 5.4 \mathrm{KCl}, 3.6 \mathrm{CaCl}_{2}, 1.0$ $\mathrm{MgCl}_{2}, 5 \mathrm{HEPES}$, and 10 glucose; $\mathrm{pH}$ was adjusted to 7.4 with $\mathrm{NaOH}$. The pipette solution used for recording $\mathrm{Ca}^{2+}$ currents contained (in $\mathrm{mM}) 125 \mathrm{CsCl}, 1.0 \mathrm{MgCl}_{2}, 5 \mathrm{HEPES}, 3 \mathrm{Mg}$-ATP, and 5 Cs-BAPTA; $\mathrm{pH}$ was adjusted to 7.3 with $\mathrm{CsOH}$. $\mathrm{K}^{+}$currents were recorded in NT solution or $\mathrm{Ca}^{2+}$-free solution, which contained (in $\mathrm{mM}$ ) $135 \mathrm{NaCl}, 5.4$ $\mathrm{KCl}, 1.0 \mathrm{MgCl}_{2}, 5$ HEPES, and 10 glucose; $\mathrm{pH}$ was adjusted to 7.4 with $\mathrm{NaOH}$. The pipette solution used for recording $\mathrm{K}^{+}$currents contained (in $\mathrm{mM}$ ) $140 \mathrm{KCl}, 1.0 \mathrm{MgCl}_{2}, 10 \mathrm{HEPES}, 5 \mathrm{Mg}$-ATP, and $10 \mathrm{EGTA}$; $\mathrm{pH}$ was adjusted to 7.3 with $\mathrm{KOH}$.

\section{Contractile activity study}

Cells plated on glass-bottom dishes were washed in PBS and then incubated in NT solution for 30 minutes. Cells were imaged on an ECLIPSE TE 300 microscope (Nikon, Japan) every 5 min from 0-45 min after exposure to $10^{-6} \mathrm{M}$ of bradykinin, $10^{-7} \mathrm{M}$ of angiotensin II, or $60 \mathrm{mM}$ of $\mathrm{KCl}$, for analysis of cell shape using ACT-2U software (Nikon, Japan).

\section{Statistical analysis}

Data are expressed as the mean \pm standard error of the mean (SEM). For a single comparison, unpaired Student's t-test was used to evaluate statistical significance. For multiple comparisons, statistical significance was evaluated by one-way ANOVA followed by Tukey's post hoc test. Differences were considered to be significant when $\mathrm{P}<0.05$.

\section{Results}

\section{Isolation of smooth muscle-like cells from bone marrow}

Five days after transfection of the SM22a promoter/GFP plasmid into the BM-derived E-ad cells, GFP was detected in a cell population (Ad $(\mathrm{G})$ cells: BM-derived smooth muscle progenitor cell: BM-SMPC) that expressed neither mature (calponin) nor immature (SMemb) SMC markers at that time (Figure 1A and 1B). Over the next 3-5 weeks, these BM-SMPCs grew into individual clones, the cells of which had a flattened appearance and gradually gained phenotypes consistent with mature smooth muscle lineage cells. Immunocytochemistry revealed individual clones/BM-derived SM-like cells (BM-derived SMCs) that were clearly

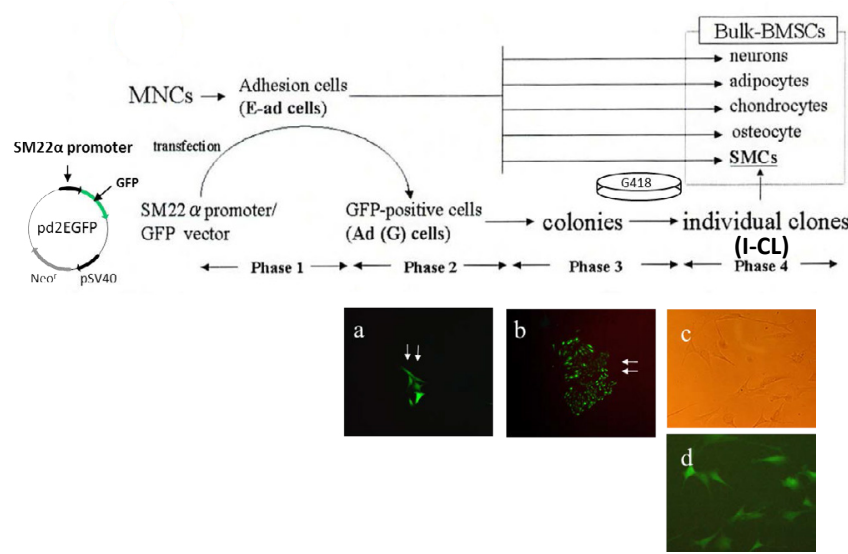

Figure 1A: Chart for illustrating the course used to acquire samples. Bone marrow mononuclear cells (MNCs) dispersed in culture dishes, part of them changed to early phase adhesion cells (E-ad cells) within 1 week. For the next 3-7 weeks, the adhesion cell fraction was grown into BMSCs that had been characterized as a mesenchymal cell population with various cell lineages including SMCs. The dashed-line quadrangle indicates that SMCs coexist with many other cell types among bulk-BMSCs. E-ad cells were transfected with the SM22a promoter/GFP construct. In the transfected E-ad cells, GFP-positive cells (Ad (G) cells) appeared 5 days after the transfection and expressed neither mature (calponin) nor immature (SMemb) SMC-specific marker proteins at that time (see section B). After G418 selection, they were grown into individual clones ( $\mathrm{I}-\mathrm{CL}$ ) that exhibited phenotypes consistent with smooth muscle lineage cells (see section $C$ ). Thus, Ad (G) cells eventually differentiated into SMCs that were presumed to be bulk-BMSCs. To clarify longitudinal transition of the expression of SMC-specific proteins, the total course is conveniently divided from phase 1 to phase 4 . As shown in lower panel, $\operatorname{Ad}(\mathrm{G})$ cells came to be detectable (lower panel a) at phase 2, and grew into colonies at phase 3 (lower panel b). In phase 4 , the colonies were picked up and investigated as individual clones (I-CL, lower panel c) with stable GFP expression (lower panel d). 
SMemb
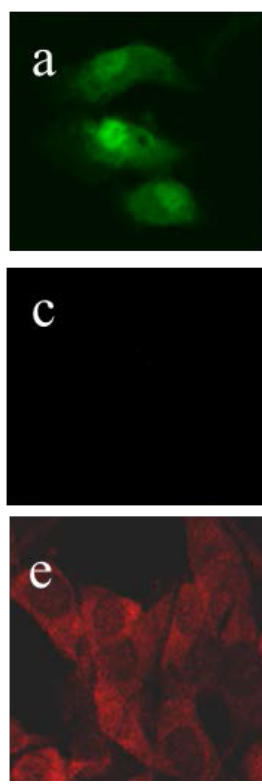

Calponin
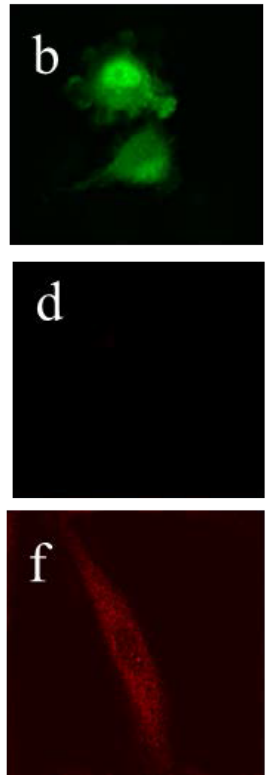

Figure 1B: Confocal photomicrographs of $\mathrm{Ad}(\mathrm{G})$ cells. Ad $(\mathrm{G})$ cells (panel a and $b$ ) were not stained by the anti-SMemb (panel c, diluted 1:1000) or anticalponin antibodies (panel d, diluted 1:100). Thus, Ad (G) cells expressed neither mature (calponin) nor immature (SMemb) SMC-specific proteins at this time. Magnification, $x$ 100. Immunostaining of NIH3T3 fibroblast cells against the SMemb antibody and native smooth muscle cells against calponin antibody were shown as positive controls (panel e and f, respectively).

\section{Calponin}
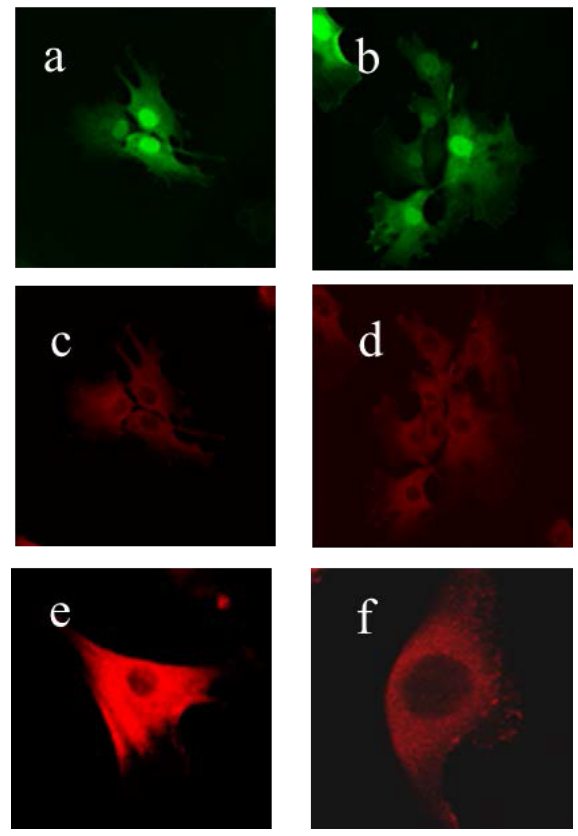

Figure 1C: Confocal photomicrographs of individual clones (I-CL) cells immunostained for calponin and SM-1. The clusters of I-CL cells (panel a and b) were clearly immunopositive for the SMC-specific proteins, calponin and SM-1 (panel $c$ and d). Magnification, $x$ 100. Immunostaining of A7r5 smooth muscle cells against the SMC-specific proteins' antibodies were shown as positive controls (panel e and f). stained for the SMC markers, calponin and SM-1 (Figure 1C).

\section{BM-derived SMCs expressed $\alpha$-SM actin}

Neither the BM-bulk-stromal cells nor the BM-SMPC populations showed staining for $a-S M$ actin. In contrast, the BM-derived SMCs clearly expressed the $\alpha$-SM actin protein (Figure 2A). Northern blot analyses also showed abundant expression of calponin and SM22 $\alpha$ at the mRNA level (Figure 2B).

\section{BM-derived SMCs exhibit four types of ion channel currents}

We used whole-cell patch clamping to detect ion channel currents in the BM-derived SMCs. Two types of $\mathrm{Ca}^{2+}$ channel currents were defined $(\mathrm{n}=22)$ : low voltage-activated $\mathrm{Ca}^{2+}$ current (LVA) and high voltage-activated $\mathrm{Ca}^{2+}$ current (HVA), with both LVA and HVA also expressed simultaneously (Figure 3A, left panel). On the other hand, the bulk-stromal cells $(n=5)$ showed no inward currents (Figure $3 \mathrm{~A}$, right panel), while BM-SMPCs $(\mathrm{n}=20)$ showed LVA inward current (10\%) or no inward current (90\%) (data not shown). The LVA and HVA inward currents were enhanced by switching from CsT solution
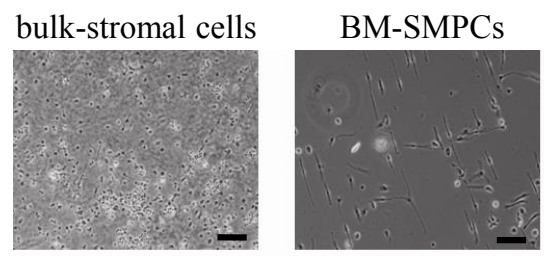

\section{BM-derived SMCs}
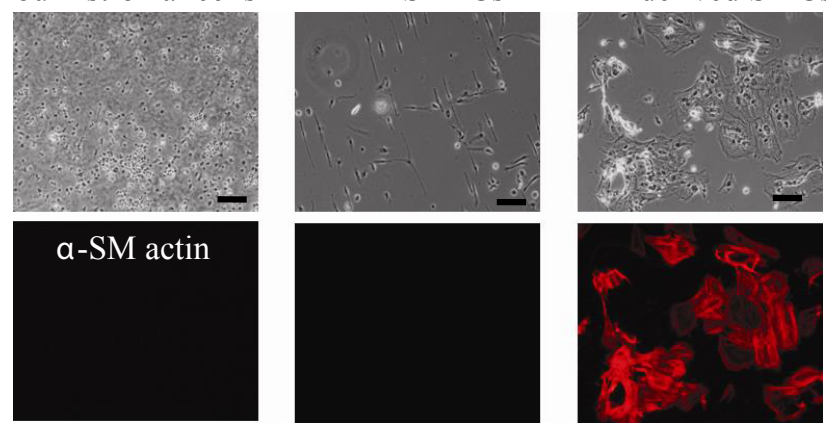

Figure 2A: No Neither BM bulk-stromal cells or Ad (G) cells/BM-SMPCs showed staining with the anti- $\alpha-S M$ actin antibodies. The clusters of I-CL cells (right panels) were clearly stained for $\alpha-S M$ actin (right lower panel). Bars, $100 \mathrm{~mm}$.

\section{Calponin}

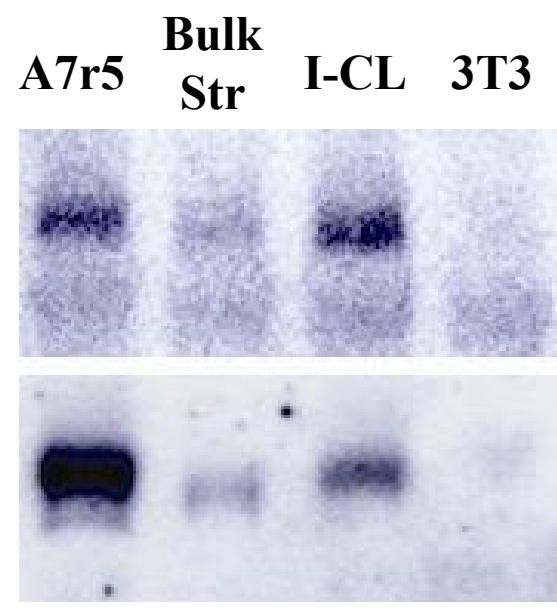

Figure 2B: mRNA levels of calponin and SM22 $\alpha$ in A7r5 cells, bulk-BMSCs, I-CL cells, and 3 T3 cells. Each sample lane was loaded with $20 \mu \mathrm{g}$ of total RNA, with $\beta$-actin expression in each sample used as an intensity control. $\mathrm{I}-\mathrm{CL}$ cells expressed both calponin and SM22 $\alpha$ at the mRNA level; while bulk-stromal cells expressed calponin mRNA at $<1 \%$ of the I-CL cell intensity (quantified with a BAS 2500 Bioimage Analyzer). The SMC line A7r5 was used as a positive control. 

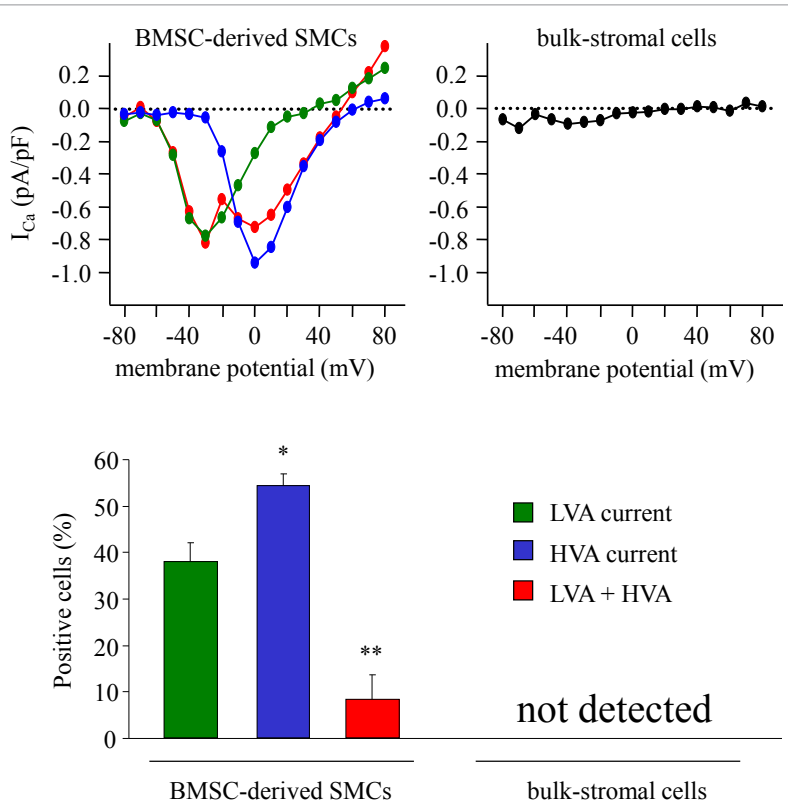

Figure 3A: The graph represents current-voltage (I-V) curves. Cells were voltage clamped at a holding potential of $-80 \mathrm{mV}$, and currents were evoked by $+10 \mathrm{mV}$ increment depolarizing steps to $+80 \mathrm{mV}$. In BMSC-derived SMCs, low voltage-activated $\mathrm{Ca}^{2+}$ current (LVA, $\bullet$ ), high voltage-activated $\mathrm{Ca}^{2+}$ current $(\mathrm{HVA}, \bullet)$, or both LVA and HVA $(\bullet)$ were recorded. In bulk-stromal cells, $\mathrm{Ca}^{2+}$ current was not detected $(\bullet)$. The percentages of showing LVA or HVA in cells are shown in lower panel. Data are expressed as the mean \pm SEM ( ${ }^{*}<<0.05,{ }^{* *} \mathrm{P}<0.01$ vs. LVA current of BMSC-derived SMCs). $n=22$ (BMSC-derived SMCs), $n=5$ (bulk-stromal cells).
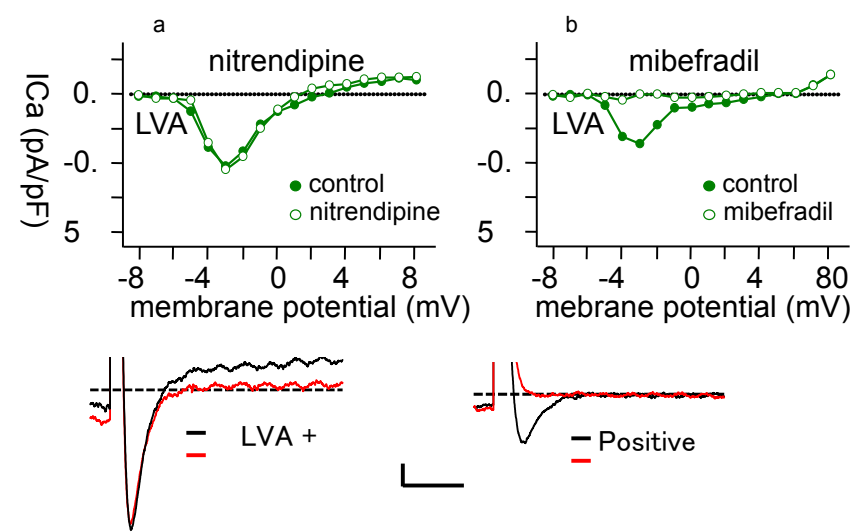

Figure 3B: The graph (panels a and b) represents I-V curves for BMSCderived SMCs with $(\circ)$ and without $(\bullet)$ inhibitor. Typical traces (panels $\mathrm{c}$ and d) show $\mathrm{I}_{\mathrm{Ca}}$ elicited by depolarization to $-30 \mathrm{mV}$ from $-80 \mathrm{mV}$ with (-) or without (-) inhibitor. A selective L-type $\mathrm{Ca}^{2+}$ channel blocker nitrendipine did not inhibit LVA current, but it was inhibited by a selective $\mathrm{T}$-type $\mathrm{Ca}^{2+}$ channel blocker mibefradil.

to high $\mathrm{Ca}^{2+}$ solution, indicating these as $\mathrm{T}$-type $\mathrm{Ca}^{2+}$ channel currents (Figure 3B) and L-type $\mathrm{Ca}^{2+}$ channel currents (Figure 3C), respectively. We also defined two types of $\mathrm{K}^{+}$channel currents in the BM-derived SMCs when switched from NT solution to $\mathrm{Ca}^{2+}$ free solution $(\mathrm{n}=4)$ : decreased $\mathrm{K}^{+}$currents $\left(\mathrm{K}_{\mathrm{Ca}}\right.$ current) and resting $\mathrm{K}^{+}$currents $\left(\mathrm{K}_{\mathrm{V}}\right.$ current) (Figure 4 , left panel). On the other hand, the bulk-stromal cells $(\mathrm{n}=4)$ showed $\mathrm{K}_{\mathrm{V}}$ current, but no $\mathrm{K}_{\mathrm{Ca}}$ current (Figure 4, right panel).

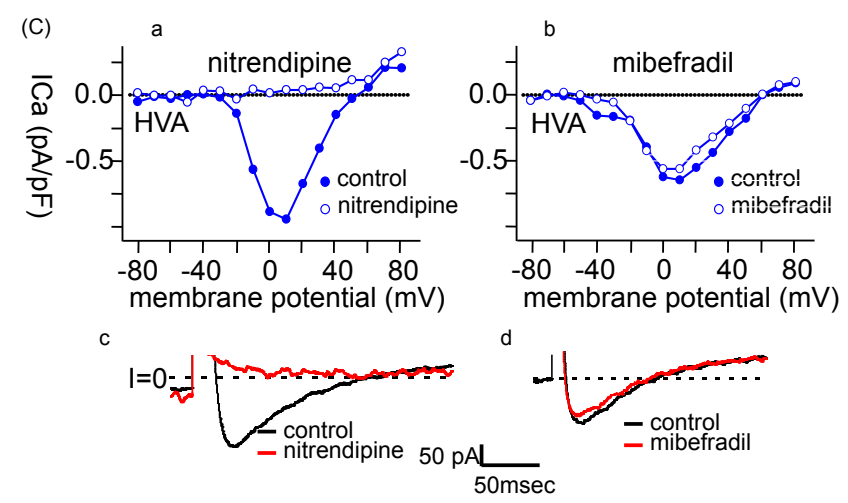

Figure 3C: The graph (panels a and b) represents I-V curves for BMSCderived SMCs with $(\circ)$ and without $(\bullet)$ inhibitor. Typical traces (panels $c$ and d) show $I_{\mathrm{Ca}}$ elicited by depolarization to $+10 \mathrm{mV}$ from $-80 \mathrm{mV}$ with (-) or without (-) inhibitor. A selective L-type $\mathrm{Ca}^{2+}$ channel blocker nitrendipine inhibited HVA current, but it was not inhibited by a selective T-type $\mathrm{Ca}^{2+}$ channel blocker mibefradil.

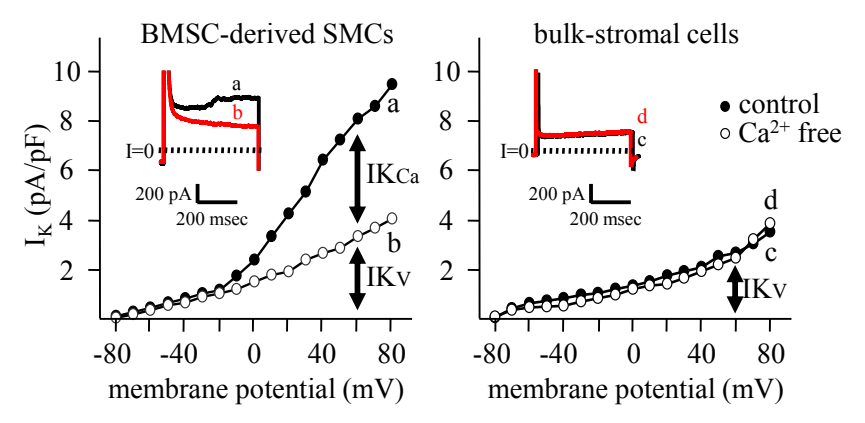

Figure 4: BM-derived SMCs show two types of $\mathrm{K}^{+}$channel currents. The graph represents I-V curves for the BM-derived SMCs and bulk-stromal cells. Ten $\mathrm{mV}$-increment depolarizing voltage steps were applied from a holding potential of $-80 \mathrm{mV}$ to $+80 \mathrm{mV}$. In BMSC-derived SMCs, switching from control solution $\left(1.8 \mathrm{mM} \mathrm{Ca}^{2+}, \bullet\right)$ to $\mathrm{Ca}^{2+}$-free solution $(\circ)$ decreased $\mathrm{K}^{+}$channel currents, indicating at least two types of $\mathrm{K}^{+}$channels present: decreased $\mathrm{K}^{+}$ current ( $\mathrm{K}_{\mathrm{Ca}}$ current) and resting $\mathrm{K}^{+}$current $\left(\mathrm{K}_{v}\right.$ current). The bulk-stromal cells showed $\mathrm{K}_{\mathrm{v}}$ current, but not $\mathrm{K}_{\mathrm{Ca}}$ current.

\section{BM-derived SMCs showed changes in $\left[\mathrm{Ca}^{2+}\right]_{i}$ in response to SMC agonists}

We assessed transient $\left[\mathrm{Ca}^{2+}\right]_{\mathrm{i}}$ changes in the BM-derived SMCs in response to SMC agonists using fura-2. Resting $\left[\mathrm{Ca}^{2+}\right]_{i}$ was approximately $250 \mathrm{nM}$ in both the BM-derived SMCs and bulk-stromal cells (Figure 5A). Exposure to bradykinin induced a rapid increase in $\left[\mathrm{Ca}^{2+}\right]_{i}$ in about $40 \%$ of BM-derived SMCs $(n=14)$ (see panel b in Figure $5 B)$, but had no such effect of the bulk-stromal cells $(n=30)$ (Figure 5A). The response was diminished after removal of bradykinin. Similarly, exposure to angiotensin II (Figure 5, lower panel) or high $\mathrm{KCl}$ induced an increase in $\left[\mathrm{Ca}^{2+}\right]_{\mathrm{i}}$ in BM-derived SMCs $(4 \mathrm{w})$, but not in bulk-stromal cells.

\section{BM-derived SMCs displayed significant contractile activity in response to SMC agonists}

The defining property of mature SMC is their ability to contract and generate force in response to vasoactive agonists. To examine whether the BM-derived SMCs generated in this study showed such functional properties, cells were imaged before and after exposure 
Citation: Hashimoto R, Nakamura K, Itoh S, Daida H, Nakazato Y, et al. (2015) Bone Marrow-Derived Regenerated Smooth Muscle Cells Have lon Channels and Properties Characteristic of Vascular Smooth Muscle Cells. J Stem Cell Res Ther 5: 257. doi:10.4172/2157-7633.1000257

Page 5 of 7

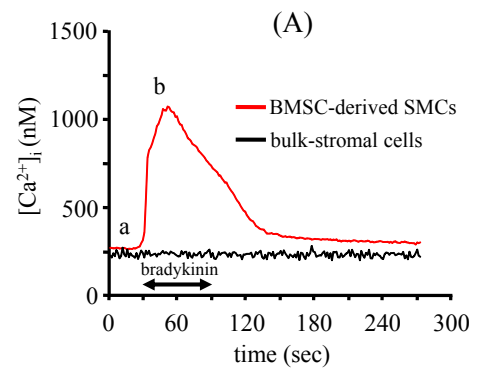

(B)
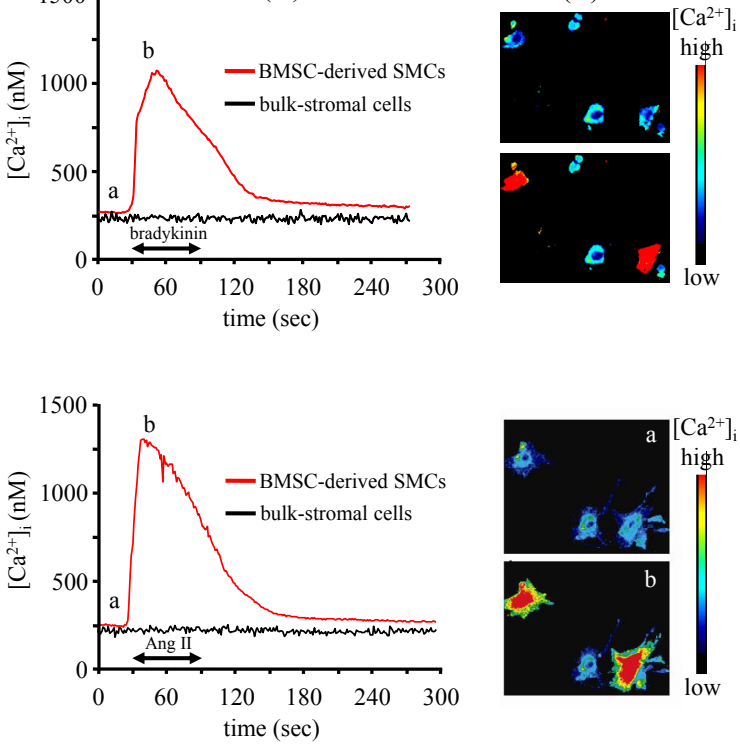

Figure 5: BM-derived SMCs showed a $\left[\mathrm{Ca}^{2+}\right]$ response to bradykinin. (A) Graph represents typical time course of $\left[\mathrm{Ca}^{2+}\right]_{\mathrm{i}}$ in cells. Exposure to bradykinin induced a rapid increase in $\left[\mathrm{Ca}^{2+}\right]_{\mathrm{i}}$ in BMSC-derived SMCs (red line), but not in bulk-stromal cells (black line). (B) Representative pseudocolor images, where red and yellow represent high and blue and black represent low $\left[\mathrm{Ca}^{2+}\right]$ concentrations. The pseudocolor images in fura-2-AM-loaded BMSC-derived SMCs ( $a$ and $b$ ) were acquired at the time corresponding to panels $a$ and $b$ in $(A)$, respectively. As shown in lower panel, BM-derived SMCs showed the same $\left[\mathrm{Ca}^{2+}\right]_{\mathrm{i}}$ response to angiotensin II.
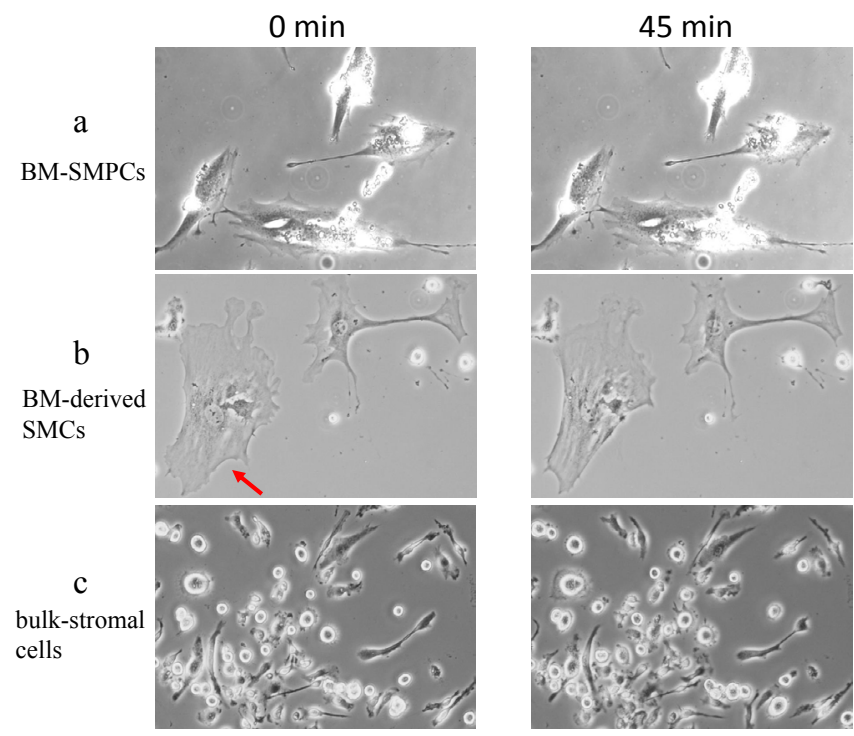

Figure 6A: The pictures represent cells before and $45 \mathrm{~min}$ after exposure to $10^{-6} \mathrm{M}$ of bradykinin. BMSC-derived SMCs showed changes in shape and sequential directional movement (panel $b$ arrow). However, BM-SMPCs and bulk-stromal cells showed only non-directional movement (panels a and c). Bars, $100 \mathrm{~mm}$.

to bradykinin. About $40 \%$ of the BM-derived SMCs $(n=20)$ showed changes in shapes and sequential directional movement (panel b in Figure 6A) that were consistent with contractile activity. Similar changes were recorded in response to other SMC agonists, angiotensin II or high $\mathrm{KCl}$ (Figure 6B and 6C). On the other hand, the bulk-stromal cells $(n=30)$ and BM-SMPCs $(n=21)$ showed only non-directional movement in response to bradykinin (Figure 6A), angiotensin $\mathrm{II}$, or high $\mathrm{KCl}$ (Figure 6B and 6C).

\section{Discussion}

The present study used SM22 $\alpha$ promoter and fluorescence-activated cell selection to define a proliferative cell population displaying biochemical and physiological characteristics of SMCs. Specifically, these BM-derived SMCs displayed contractile activity and expressed many ion channels critical for their contractile behavior comparable

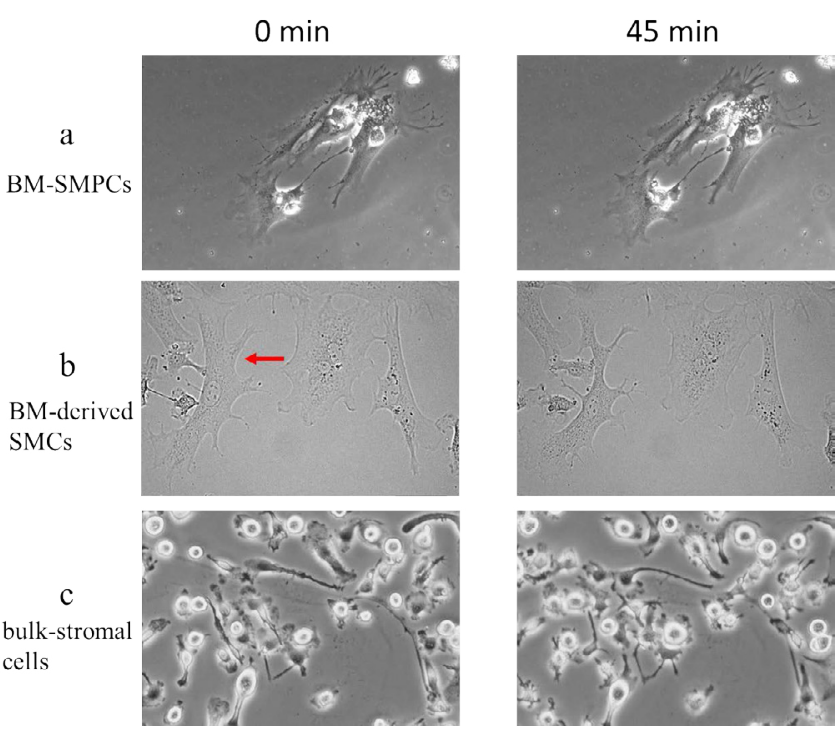

Figure 6B: The pictures represent cells before and $45 \mathrm{~min}$ after exposure to $10^{-7} \mathrm{M}$ of angiotensin II. BMSC-derived SMCs showed changes in shape and sequential directional movement (panel $b$ arrow). However, BM-SMPCs and bulk-stromal cells showed only non-directional movement (panels a and c).

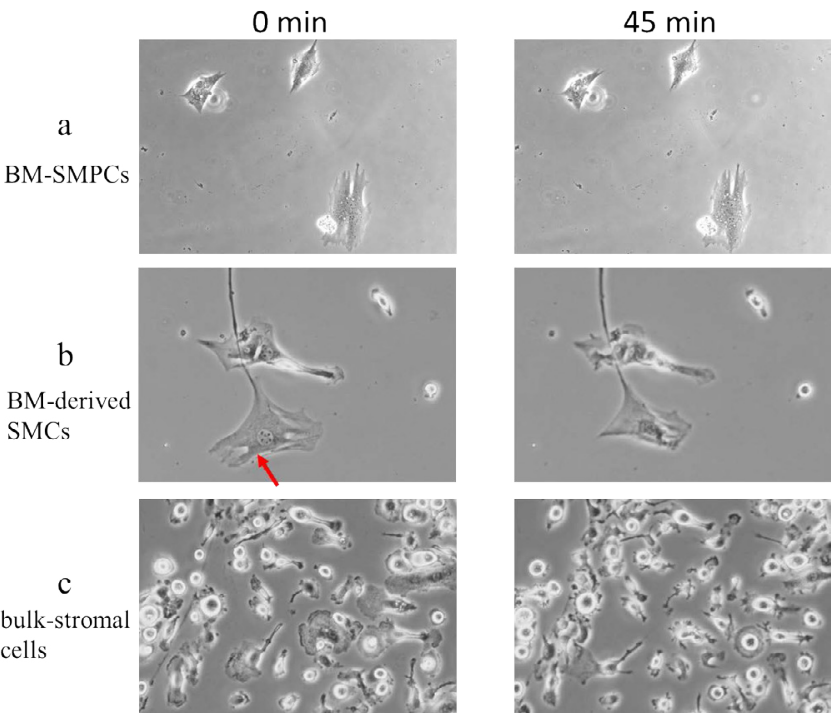

Figure 6C: The pictures represent cells before and $45 \mathrm{~min}$ after exposure to $60 \mathrm{mM} \mathrm{KCl}$. BMSC-derived SMCs showed changes in shape and sequential directional movement (panel $\mathrm{b}$ arrow). However, BM-SMPCs and bulk-stromal cells showed only non-directional movement (panels a and c). 
to those of native vascular SMCs. Importantly, the differentiated BMderived cells, but not their precursors, exhibited the functional ability to contract and relax in direct response to pharmacological agents.

Assessing stem cell differentiation should involve not only identifying structural proteins and transcription factors consistent with a differentiated cell type, but also the demonstration of differentiatedcell functions. We previously reported and established a SM22a promoter to select for SMCs from BM stromal cells [3]. Putative BMSMPCs, named Ad (G) cells, showed an active SM22 $\alpha$ promoter and expressed neither immature nor mature SMC markers. G418 selection for 21 days produced clones of cells expressing SMC marker proteins and transcripts, suggesting that a fraction of the cells with active SM22a promoter differentiated into smooth muscle like cells. The present study investigated, using the SM22 $\alpha$ promoter and fluorescence-activated cell selection, to clarify those BM-SMPCs and differentiated BM-derived SMCs exhibit both biochemical and physiological characteristics of SMC function.

The construction of stable blood vessels is a fundamental challenge for tissue engineering in regenerative medicine. Although the use of human cells in low-pressure applications $(<20 \mathrm{mmHg})$ has achieved significant clinical success in pediatrics [13], the promise of a tissueengineered graft for adult arterial revascularization remains unrealized [14]. The in vivo mechanical functioning of native arteries is mainly governed by elastin and activated SMCs at physiological pressure. McAllister et al. [15] clearly revealed that aneurysms developing in some grafts after implantation were attributable to the selection of fibroblasts as a cell source. It is therefore feasible that vascular grafts biofabricated from fibroblasts would contain insufficient elastin and be prone to aneurysms developing due to collagen fatigue. The one way to overcome these limitations is to select another cell source capable of differentiating into vascular SMCs under optimum perfusion conditions in a bioreactor [1] (such as BM-derived mesenchymal stem cells). Such cells could successfully and sufficiently supply both elastin and collagen. Thus, our established BM-SMPC population seems to be a good candidate for constructing tissue-engineered grafts for adult arterial revascularization.

Contractile activity is the defining property of mature SMC and one of the most important properties of blood vessels. The BM-derived SMCs generated in the present study displayed changes in shape and sequential directional movement in response to vasoconstrictors such as bradykinin, angiotensin II, and high $\mathrm{KCl}$. High $\mathrm{KCl}$ concentration induces muscle contraction by opening the L-type [16], slow, calcium potential-dependent channels, while angiotensin II acts through angiotensin II receptors type- 1 and type-2, and bradykinin acts through bradykinin receptors. The BM-derived SMCs therefore showed both non-receptor- and receptor-mediated pathways of vascular reactivity. In contrast, the bulk-stromal cells and BM-SMPCs displayed no contractility, apart from some non-directional movement in response to bradykinin, angiotensin $\mathrm{II}$, and high $\mathrm{KCl}$, indicating that $\mathrm{BM}$ contains only a small proportion of functional SMCs that retain their biochemical and contractile properties after purification and expansion in vitro.

SMCs express many ion channels and membrane receptors critical for contractile behavior mediated through the $\mathrm{Ca}^{2+} /$ calmodulindependent phosphorylation of myosin light chain [17]. Influx of $\mathrm{Ca}^{2+}$ from voltage-activated $\mathrm{Ca}^{2+}$ channels and intracellular stores is the major source of $\mathrm{Ca}^{2+}$ for contraction. In cardiomyocytes and vascular SMCs, the most important $\mathrm{Ca}^{2+}$-activated channels are the L-type $\mathrm{Ca}^{2+}$ channels [17]. Using whole-cell patch clamping, we demonstrated functional L-type channels on the BM-derived SMCs that were not present on either undifferentiated BMSCs or BM-SMPCs selected with SM22a GFP alone. Functional L-type channels could be detected 4 weeks after the GFP selection, at current densities similar to those in rat aortic SMCs. These results are consistent with further maturation of the BM-derived SMCs after a few passages, as previously shown by SM1/2 expression patterns [3].

Recently, murine embryonic stem (ES) cells [18] and different types of primary adult stem/progenitor cellsincluding mesenchymal stem cells [19] (MSCs), BM-derived multipotent stem cells [20], neural stem cells [21], mesoangioblasts [22], and hair-foricle cells [23] have been used to elucidate signals that induce commitment and differentiation of SMCs. The iPS cells [24] also differentiate into all three germ layers including $a-S M$ actin-positive cells. Although most of these studies demonstrated protein expressions consistent with SMCs, few characterized the differentiated cells for functional properties of SMCs. One exceptional study revealed that human amniotic fluid stem cells (hAFSCs) under selective culture conditions are able to give rise to functional SMCs [25]. However, they have shown the presence only of the delayed rectifier and $\mathrm{Ca}^{2+}$-dependent $\mathrm{K}^{+}$currents in hAFSCs-derived SMCs. It has been reported that both $\mathrm{L}$-type and T-type $\mathrm{Ca}^{2+}$-channel expression patterns [26] are regulated during SMC development [27]. The current electrophysiological experiments using the patch-clamp technique showed 4 types of channels including both L-type and T-type $\mathrm{Ca}^{2+}$ channel expression in the BM-derived SMCs. The previous study also attempted to culture SMCs from bone marrow hAFSCs by stimulation with cytokines and growth factors such as PDGF-BB and TGF- $\beta$ [25]. Although soluble factors in the medium can differentiate a fraction of cells toward the SMC lineage, these approaches carry potential clinical risks with respect to overly accelerating cell proliferation and mutagenesis. Moreover, the dilemmas in using hAFSCs for constructing tissue-engineered vascular grafts for adults induced alloreactivity. Thus, our established BM-derived SMC using the SM22a promoter and fluorescence-activated cell selection could be a reliable source of healthy SMCs that can be safely harvested and that require minimal manipulation for constructing tissue-engineered vessels.

In conclusion, we have demonstrated that BM-derived SMCs express SMC-specific proteins and ion channels in a temporally appropriate fashion and display functional attributes similar to primary vascular SMC populations, making them a good candidate stem cell population for developmental studies and tissue engineering. Most importantly, these BM-derived SMCs displayed contractility and expressed many ion channels critical for cellular contractile behavior that are comparable to native matured vascular SMCs. The robust differentiation from BM-SMPCs to nearly homogeneous populations of SMCs described here will allow us to further characterize the molecular processes underlying SMC differentiation. Since BM-derived $\mathrm{Ad}(\mathrm{G})$ cells have the potential to differentiate into functional SMCs, BMSC tissue could be a useful source of cells for treating injured tissues where smooth muscle plays an important role, including regenerative tissueengineered blood vessels for revascularization.

\section{References}

1. Mironov V, Kasyanov V (2009) Emergence of clinical vascular tissue engineering. Lancet 373: 1402-1404. [PubMed]

2. Katoh Y, Periasamy M (1996) Growth and differeniation of smooth muscle cells during vascular development. Trends Cardiovasc Med 6: 100-106. [PubMed]

3. Kashiwakura Y, Katoh Y, Tamayose K, Konishi H, Takaya N, et al. (2003) Isolation of bone marrow stromal cell-derived smooth muscle cells by a human SM22 alpha promoter: in vitro differentiation of putative smooth muscle progenitor cells of bone marrow. Circulation 107: 2078-2081. [PubMed] 
Citation: Hashimoto R, Nakamura K, Itoh S, Daida H, Nakazato Y, et al. (2015) Bone Marrow-Derived Regenerated Smooth Muscle Cells Have lon Channels and Properties Characteristic of Vascular Smooth Muscle Cells. J Stem Cell Res Ther 5: 257. doi:10.4172/2157-7633.1000257

4. Orlic D, Kajstura J, Chimenti S, Jakoniuk I, Anderson SM, et al. (2001) Bone marrow cells regenerate infarcted myocardium. Nature 410: 701-705. [PubMed]

5. Majumdar MK, Thiede MA, Mosca JD, Moorman M, Gerson SL (1998) Phenotypic and functional comparison of cultures of marrow-derived mesenchymal stem cells (MSCs) and stromal cells. J Cell Physiol 176: 57-66. [PubMed]

6. Gartner S, Kaplan HS (1980) Long-term culture of human bone marrow cells. Proc Natl Acad Sci USA 77: 4756-4759. [PubMed]

7. Solway J, Seltzer J, Samaha F, Kim S, Alger LE, et al. (1995) Structure and expression of a smooth muscle cell-specific gene, SM22 alpha. J Biol Chem 270: 13460-13469. [PubMed]

8. Katoh Y, Loukianov E, Periasamy M (1994) Identification of functional promoter elements in the rabbit smooth muscle myosin heavy chain gene. J Biol Chem 269: 30538-30545. [PubMed]

9. Takahashi K, Nadal-Ginard B (1991) Molecular cloning and sequence analysis of smooth muscle calponin. J Biol Chem 266: 13284-13288. [PubMed]

10. Katoh Y, Komuro I, Takaku F, Yamaguchi H, Yazaki Y (1990) Messenger RNA levels of guanine nucleotide-binding proteins are reduced in the ventricle of cardiomyopathic hamsters. Circ Res 67: 235-239. [PubMed]

11. Grynkiewicz G, Poenie M, Tsien RY (1985) A new generation of Ca2+ indicators with greatly improved fluorescence properties. J Biol Chem 260: 3440-3450. [PubMed]

12. Neher E, Sakmann B (1976) Single-channel currents recorded from membrane of denervated frog muscle fibres. Nature 260: 799-802. [PubMed]

13. Shin'oka T, Imai Y, Ikada $Y$ (2001) Transplantation of a tissue-engineered pulmonary artery. N Engl J Med 344: 532-533. [PubMed]

14. Niklason LE (1999) Techview: medical technology. Replacement arteries made to order. Science 286: 1493-1494. [PubMed]

15. McAllister TN, Maruszewski M, Garrido SA, Wystrychowski W, Dusserre N, et al. (2009) Effectiveness of haemodialysis access with an autologous tissueengineered vascular graft: a multicentre cohort study. Lancet 373: 1440-1446. [PubMed]

16. Richard S, Neveu D, Carnac G, Bodin P, Travo P, et al. (1992) Differentia expression of voltage-gated Ca $(2+)$-currents in cultivated aortic myocytes. Biochim Biophys Acta 1160: 95-104. [PubMed]
17. Moosmang S, Lenhardt P, Haider N, Hofmann F, Wegener JW (2005) Mouse models to study L-type calcium channel function. Pharmacol Ther 106: $347-$ 355. [PubMed]

18. Sinha S, Wamhoff BR, Hoofnagle MH, Thomas J, Neppl RL, et al. (2006) Assessment of contractility of purified smooth muscle cells derived from embryonic stem cells. Stem Cells 24: 1678-1688. [PubMed]

19. Galmiche MC, Koteliansky VE, Brière J, Hervé P, Charbord P (1993) Stromal cells from human long-term marrow cultures are mesenchymal cells that differentiate following a vascular smooth muscle differentiation pathway. Blood 82: 66-76. [PubMed]

20. Yoon YS, Wecker A, Heyd L, Park JS, Tkebuchava T, et al. (2005) Clonally expanded novel multipotent stem cells from human bone marrow regenerate myocardium after myocardial infarction. J Clin Invest 115: 326-338. [PubMed]

21. Tsai RY, McKay RD (2000) Cell contact regulates fate choice by cortical stem cells. J Neurosci 20: 3725-3735. [PubMed]

22. Tagliafico E, Brunelli S, Bergamaschi A, De Angelis L, Scardigli R, et al. (2004) TGFbeta/BMP activate the smooth muscle/bone differentiation programs in mesoangioblasts. J Cell Sci 117: 4377-4388. [PubMed]

23. Liu JY, Peng HF, Andreadis ST (2008) Contractile smooth muscle cells derived from hair-follicle stem cells. Cardiovasc Res 79: 24-33. [PubMed]

24. Takahashi K, Yamanaka S (2006) Induction of pluripotent stem cells from mouse embryonic and adult fibroblast cultures by defined factors. Cell 126 663-676. [PubMed]

25. Ghionzoli M, Repele A, Sartiani L, Costanzi G, Parenti A, et al. (2013) Human amniotic fluid stem cell differentiation along smooth muscle lineage. FASEB $J$ 27: 4853-4865. [PubMed]

26. Hashimoto R, Katoh Y, Itoh S, lesaki T, Daida H, et al. (2010) T-type Ca2+ channel blockers increase smooth muscle progenitor cells and endothelial progenitor cells in bone marrow stromal cells in culture by suppression of cell death. Ann Vasc Dis 3: 117-126. [PubMed]

27. Hashimoto $R$, Katoh $Y$, Nakamura K, Itoh S, lesaki T, et al. (2012) Enhanced accumulation of adipocytes in bone marrow stromal cells in the presence of increased extracellular and intracellular $\left[\mathrm{Ca}^{2+}\right]$. Biochem Biophys Res Commun 423: 672-678. [PubMed] 